\title{
MDM2 as a target for ellagic acid-mediated suppression of prostate cancer cells in vitro
}

\author{
YASIR I. MOHAMMED SALEEM and MUSTAFA I. SELIM \\ Department of Pharmacology and Toxicology, Brody School of Medicine, East Carolina University, \\ Greenville, NC 27858, USA
}

Received December 6, 2019; Accepted May 8, 2020

DOI: $10.3892 /$ or.2020.7664

\begin{abstract}
Prostate cancer (PCa) is the most common cancer in men. Despite the available treatments for $\mathrm{PCa}$, a significant number of patients relapse as the disease becomes hormonal-independent. p53 is a common tumor suppressor; however, its activity is diminished via the overexpression of murine double minute-2 (MDM2). The pomegranate, walnuts, and blueberries are widely consumed fruits and nuts that contain several polyphenolic compounds, mainly ellagic acid (EA). The present study focused on the influence of EA on the p53/MDM2 pathway in PCa cell lines. Three human PCa cell lines PCa LNCaP (p53 $\left.3^{+/+}\right), 22 \mathrm{RV} 1\left(\mathrm{p} 53^{-/+}\right)$, and PC3 (p53-/harboring different p53 genotypes were used in this research. We found that EA downregulated the gene and protein expression levels of MDM2 and increased the protein expression of p53 as determined by qPCR and western blot analyses. Moreover, by using western blot analysis, we determined that EA increased the protein expression of the p53 target proteins p21, p53 upregulated modulator of apoptosis (PUMA) [also known as Bcl-2-binding component 3 (BBC3)] and Phorbol-12-myristate-13-acetate-induced protein 1 (NOXA). Furthermore, we found that EA induced apoptosis in the absence of p53 by downregulating MDM2 and X-linked inhibitor of apoptosis protein (XIAP) protein expressions as determined by western blot analysis. We conclude that EA suppressed PCa cells in vitro partly by downregulating MDM2.
\end{abstract}

\section{Introduction}

Prostate cancer (PCa) is the most common cancer in men and the second leading cause of cancer-related mortality in men worldwide (1). Because of the limited treatment options available for $\mathrm{PCa}$, patients may experience disease relapse and are often treated with anti-androgen therapy (2).

Correspondence to: Dr Mustafa I. Selim, Department of Pharmacology and Toxicology, Brody School of Medicine, East Carolina University, E 5th Street, Greenville, NC 27858, USA

E-mail: selimm@ecu.edu

Key words: polyphenols, ellagic acid, MDM2, p53, prostate cancer
However, advanced $\mathrm{PCa}$ results from the emergence of androgen-independent PCa and eventually must be treated with chemotherapy. Although docetaxel-based therapy is mostly used in advanced $\mathrm{PCa}$, patients show low survival rates when taking docetaxel, limiting the treatment options available for advanced $\mathrm{PCa}$ (3). Therefore, targeting PCa independently with chemotherapy is crucial. p53 is a transcription factor known as the guardian of the genome because it is involved in the transcription of regulatory genes that control cell apoptosis, cell cycle arrest, and DNA repair (4). p53 causes cell-cycle arrest by activating the cyclin-dependent kinase inhibitor p21 (4). In addition, p53 induces apoptosis by activating the mitochondrial pro-apoptotic proteins p53 upregulated modulator of apoptosis (PUMA) [also known as Bcl-2-binding component 3 (BBC3)] and Phorbol-12-myristate-13-acetate-induced protein 1 (NOXA) (5). p53 undergoes post-translation modification (PTM) at several sites in response to DNA damage and oncogene activation in a cell $(4,6)$. The p53 PTM enables it to be activated and stabilized after DNA damage (4). It was previously shown that phosphorylation and acetylation of p53 enhance the transcription of its target genes (7-9). On the other hand, p53 also undergoes ubiquitination and sumoylation, which are associated with the nuclear export of p53 and with the inhibition of p53 transcriptional activities (10-12). The TP53 gene is mutated in about $50 \%$ of cancers $(13,14)$. On the other hand, p53 still retains its wild-type status in about $50 \%$ of carcinomas, but its activity is diminished. Murine double minute-2 (MDM2), an E3 ligase enzyme, is the major negative regulator of p53 that is overexpressed in half of the cancers, including PCa (15). MDM2 is also a target gene for p53, helping to establish an autoregulatory feedback loop in which p53 promotes the transcription of its negative regulator (16). MDM2 regulates $\mathrm{p} 53$ by three main mechanisms, as follows: It inhibits p53 transcriptional activity, exports p53 from the nucleus, and ubiquitinates p53 and degrades it in the proteasome $(17,18)$. Thus, MDM2 becomes a promising target for cancer therapy in cancers that are harboring wild-type p53 (19). Although MDM2 is the main negative regular of $\mathrm{p} 53$, it also regulates other proteins independently of p53 (16). Among these proteins is X-linked inhibitor of apoptosis protein (XIAP) protein that is known for its inhibition to caspase 3 (18).

Epidemiological studies, including PCa cell lines and in vivo xenograft models, suggest that the consumption of a selected variety of fruits and vegetables rich in polyphenolic compounds 
is effective against several types of cancer $(20,21)$. The pomegranate, a widely consumed fruit, suppresses the growth of several cancers, including PCa $(22,23)$. The effect of the pomegranate on cancers is attributed to its polyphenolic compounds, particularly ellagic acid (EA) and urolithin A (UA), which are potent antioxidants with anticancer activity $(24,25)$. Previous studies have shown that EA causes PCa cell inhibition, cell cycle arrest, and apoptosis in 22RV1, DU-145, PC3, and LNCaP PCa cell lines $(23,26-28)$. In addition, EA has been shown to inhibit vascular endothelial growth factor in LNCaP cells, which is responsible for cancer angiogenesis (29). In addition to the in vitro studies, some investigators have extended the in vitro observation to in vivo. For example, using immunodeficient murine models of $\mathrm{PCa}$, the authors found EA reduced angiogenesis and metastasis formation (30). However, these effects were not by EA alone since EA was given in combination with other polyphenols, luteolin, and punicic acid (30). Another study showed that EA inhibited PCa carcinogenesis in vivo (25). Thus, EA interferes with multiple biological processes involved in PCa initiation, angiogenesis, and metastasis (31). Although these and other investigations have confirmed the anticancer effect of EA on PCa, the mechanisms by which EA influences the p53/ MDM2 pathway in PCa remain incompletely understood. We have recently demonstrated that EA's metabolite, UA, increased p53 expression, and inhibited MDM2-mediated p53 polyubiquitination (32). The aim of the present study was to investigate the influence of EA on the p53/MDM2 signaling pathway in $\mathrm{PCa}$ cells. Here, we confirmed the effect of the parent compound, EA, on the p53/MDM2 pathway by downregulating MDM2 and upregulating p53. Our data suggest that EA suppresses PCa progression partly via targeting the p53/MDM2 pathway.

\section{Materials and methods}

Cell cultures. Human PCa LNCaP, 22RV1, and PC3 cell lines were obtained from the American Type Culture Collection (ATCC). Both LNCaP and 22RV1 cell lines were grown using RPMI-1640 media (ATCC) containing 10\% fetal bovine serum (FBS), penicillin $(100 \mathrm{mg} / \mathrm{ml})$ and streptomycin $(100 \mathrm{mg} / \mathrm{ml})$. PC3 cells were grown using F12 knight media (ATCC) containing 10\% FBS, penicillin $(100 \mathrm{mg} / \mathrm{ml})$ and streptomycin $(100 \mathrm{mg} / \mathrm{ml})$. Mouse embryonic fibroblast (MEF) cells possessing double knockouts of p53 and MDM2 $\left(\mathrm{p}^{2} 3^{-/-} \mathrm{MDM}^{-/-}\right.$) were obtained from Professor Guillermina Lozano (MD Anderson Cancer Center, University of Texas, Austin, TX, USA). Wild-type MEF cells were obtained from ATCC. Both wild-type MEF and MEF (p53 ${ }^{-/-} \mathrm{MDM}^{-/-}$) were grown using DMEM media (ATCC) containing $10 \%$ fetal bovine serum (FBS), penicillin $(100 \mathrm{mg} / \mathrm{ml})$ and streptomycin $(100 \mathrm{mg} / \mathrm{ml})$. All cell lines were grown in a $37^{\circ} \mathrm{C}$ incubator with $5 \% \mathrm{CO}_{2}$ according to ATCC protocols.

Reagents and antibodies. EA was purchased from Santa Cruz Biotechnology, Inc. Anti-cleaved PARP (cat. no. 5625), anti-cleaved caspase-3 (cat. no. 9661), anti-phospho-MDM2ser166 (cat. no. 3521), anti-p14ARF (cat. no. 2407) anti-PUMA (cat. no. 12450), anti-NOXA (cat. no. 14766), anti-phospho-p53-ser15 (cat. no. 9284), anti-phospho-p53-ser 20 (cat. no. 9287), anti-XIAP (2042T), anti-GAPDH (cat. no. 2118) and anti- $\beta$-actin (cat. no. 3700 ) antibodies were purchased from
Cell Signaling Biotechnology, Inc. Anti-MDM2 antibody (cat. no. 556353) was purchased from BD Biosciences. Anti-p53 (sc-126) and anti-p21 (sc-6246) antibodies were purchased from Santa Cruz Biotechnology, Inc.

Cell viability assay. All cells were incubated in 96-well plates overnight at a concentration of 120,000 cells $/ \mathrm{ml}$ to allow them to adhere and to reach $70 \%$ confluency before treatment. Cells were then treated with EA at concentrations of 5, 10, 20, 40, 80 and $160 \mu \mathrm{M}$. DMSO was used to dissolve EA and was used as a control (CTRL) at a final concentration of $0.08 \%$, while staurosporine (ST) was used as a positive control. Cell viability was measured using the CellTiter-Glo ${ }^{\circledR}$ luminescent assay (Promega Corp.) after 24 and 48 h of EA treatment according to the manufacturer's protocol.

Immunoblotting (IB). Immunoblotting was conducted as described previously (33). Cells were cultured in $100-\mathrm{mm}$ plates at a concentration of 120,000 cells/ml and incubated for $24 \mathrm{~h}$ in a $37^{\circ} \mathrm{C}$ incubator. Following incubation, cells were treated for 24 or $48 \mathrm{~h}$ with either EA $(20,40$ and $80 \mu \mathrm{M})$ or vehicle control prepared in serum-free medium. Protein lysates were extracted using $1 \mathrm{X}$ cell lysis buffer containing $20 \mathrm{mM}$ Tris- $\mathrm{HCl}$ ( $\mathrm{pH} 7.5)$ $150 \mathrm{mM} \mathrm{NaCl}, 1 \mathrm{mM} \mathrm{Na}{ }_{2}$ EDTA, $1 \mathrm{mM}$ EGTA, $1 \%$ Triton, $2.5 \mathrm{mM}$ sodium pyrophosphate, $1 \mathrm{mM} \beta$-glycerophosphate, $1 \mathrm{mMNa}_{3} \mathrm{VO}_{4}$ and $1 \mu \mathrm{g} / \mathrm{ml}$ leupeptin (Cell Signaling Technology, Inc.). The dishes were then scraped, and the lysate was collected in a microcentrifuge tube and placed on ice for $30 \mathrm{~min}$. The lysate was then passed through a 21-gauge needle to break up the cell aggregates. The cell lysate was centrifuged at $14,000 \mathrm{x} \mathrm{g}$ for $10 \mathrm{~min}$ and was quantified by BCA reagent (Thermo Fisher Scientific, Inc.). An amount $30 \mu \mathrm{g}$ of protein lysate for each sample was loaded equally onto SDS-PAGE for separation using gradient (4-20\%) gels (Bio-Rad Laboratories). The gel was then transferred to a nitrocellulose membrane (Bio-Rad Laboratories) using Trans-Blot Turbo Transfer System (Bio-Rad Laboratories) with transfer buffer (containing $230 \mathrm{mM}$ glycine, $25 \mathrm{mM}$ Tris, $0.7 \mathrm{mM}$ SDS, 20\% methanol). The membrane was then blocked using Odyssey blocking buffer (LI-COR Biosciences) for $1 \mathrm{~h}$ at room temperature to block the nonspecific binding sites on the membrane. The membrane was then incubated at $4^{\circ} \mathrm{C}$ overnight with blocking buffer containing p53 (1:1,000), p-p53-ser 15 (1:1,000),p-p53-ser20 (1:1,000), MDM2 (1:500), p-MDM2 ser166 $(1: 1,000)$, p21 $(1: 500)$, cleaved caspase $3(1: 1,000)$, cleaved PARP (1:1,000), p14ARF (1:500), NOXA (1:500), PUMA (1:1,000), XIAP $(1: 1,000)$, GAPDH $(1: 1,000)$ and $\beta$-actin $(1: 1,000)$. The membrane then was washed three times with Tris-buffered saline with $0.1 \%$ Tween 20 (TBST), and then incubated for $1 \mathrm{~h}$ at room temperature with a blocking buffer containing the appropriate secondary antibody $(1: 15,000)$. Protein bands were visualized using the LI-COR Odyssey CLx imaging system (LI-COR Biosciences). The loading controls used for western blotting were GAPDH and $\beta$-actin. The densitometry for each band was measured using Image J 1.5k software (National Institutes of Health, Bethesda). Each band was normalized to its corresponding loading control as shown on the y-axis for each quantitative analysis of the western blot.

Quantitative real-time polymerase chain reaction ( $R T-q P C R)$. PCa cells were treated with 40 and $80 \mu \mathrm{M}$ of EA for $24 \mathrm{~h}$ for 

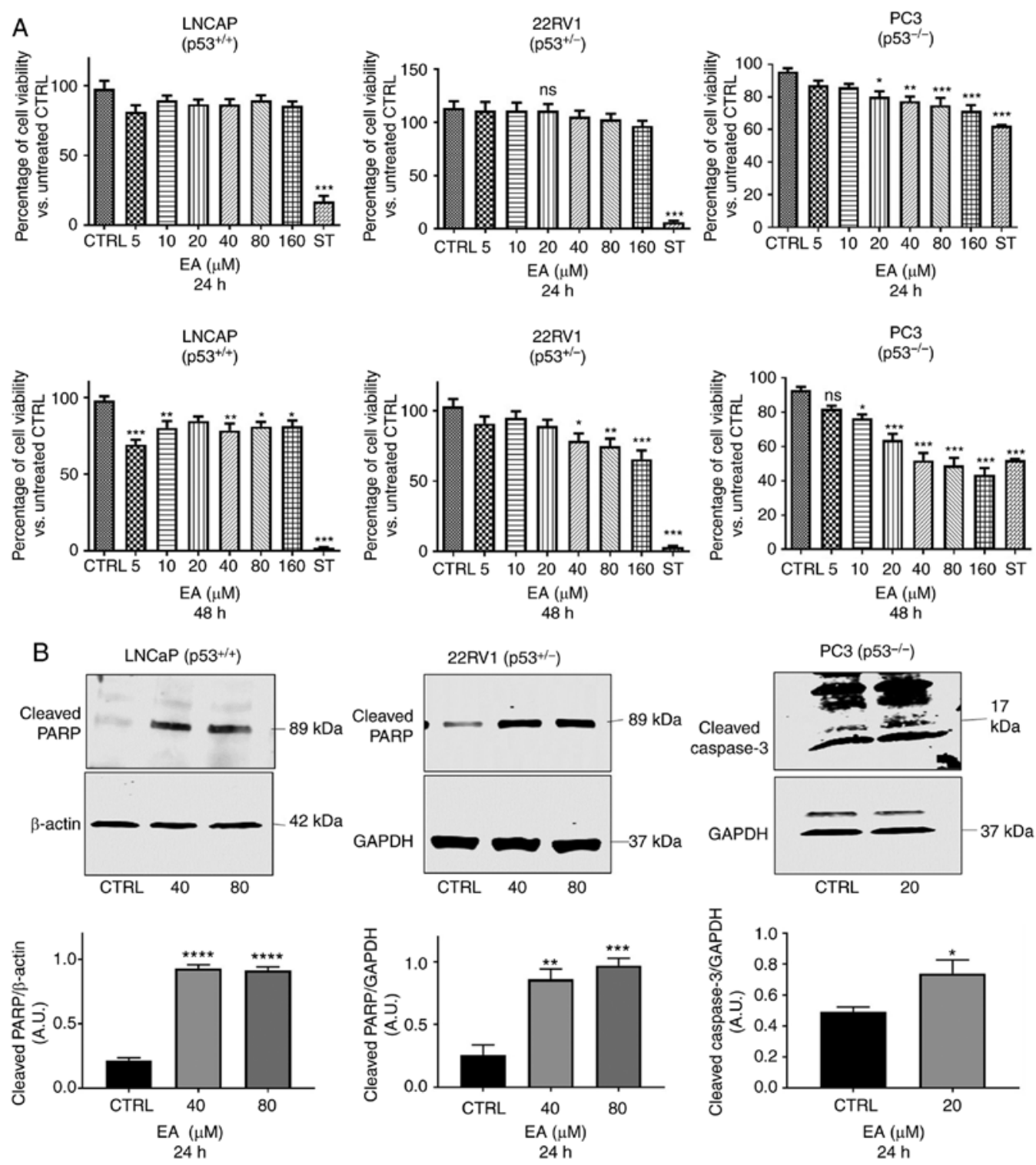

Figure 1. (A) Cell viability assay for the effect of EA on PCa cell lines. Cell Titer-Glo assays were performed to determine the cell viability of LNCaP, 22RV1 and PC3 cells following treatment with EA at concentrations of $0-160 \mu \mathrm{M}$ for $24 \mathrm{~h}$ (top panels) and $48 \mathrm{~h}$ (lower panels). The percentages of viable cells were determined relevant to untreated cells as compared to vehicle control (CTRL). One-way ANOVA of three measurements in triplicate (mean \pm SEM) was performed. ${ }^{*} \mathrm{P}<0.05,{ }^{* *} \mathrm{P}<0.01,{ }^{* * * *} \mathrm{P}<0.001$ significant results of different concentrations. of EA vs. CTRL (vehicle control); ns, not significant; ST, staurosporine. (B) Representative western blotting of cleaved PARP protein expression in PCa LNCaP and 22RV1 cells with their corresponding quantitative analyses. EA significantly increased the protein expression of cleaved PARP in LNCaP (40 and $80 \mu \mathrm{M}, \mathrm{P} \leq 0.0001)$ and in $22 \mathrm{RV} 1$ cells $(40 \mu \mathrm{M}, \mathrm{P}=0.023 ; 80 \mu \mathrm{M}, \mathrm{P}=0.0009)$. Also, EA significantly increased the protein expression of cleaved caspase 3 in PC 3 cells $(20 \mu \mathrm{M}, \mathrm{P}=0.0476)$. Results are expressed as arbitrary units (A.U.) and represent the means \pm SEM of 3 experiments ${ }^{*} \mathrm{P}<0.05,{ }^{* *} \mathrm{P}<0.01,{ }^{* * * *} \mathrm{P}<0.001,{ }^{* * * * *} \mathrm{P}<0.0001$ significant results of 40 and $80 \mu \mathrm{M}$ EA vs. CTRL (vehicle control). $\mathrm{PCa}$, prostate cancer; EA, ellagic acid; PARP, poly(ADP-ribose) polymerase.

22RV1 and LNCaP cell lines, respectively, and $20 \mu \mathrm{M}$ of EA for PC3 cells also for $24 \mathrm{~h}$. Total RNA was extracted and purified from the cell lines using the miRNeasy Mini kit (Qiagen) according to the manufacturer's guidelines. The complementary DNA was generated from the total RNA by using the iScript cDNA Synthesis kit (Bio-Rad Laboratories). The quantitative real-time polymerase chain reaction was performed with a real-time thermal cycler (Bio-Rad Laboratories) using SsoAdvanced ${ }^{\mathrm{TM}}$ Universal SYBR ${ }^{\circledR}$ Green Supermix (Bio-Rad Laboratories). RT-qPCR reactions were conducted for 40 cycles. Each cycle included denaturation $\left(95^{\circ} \mathrm{C}\right.$ for $\left.39 \mathrm{sec}\right)$, annealing $\left(57^{\circ} \mathrm{C}\right.$ for $\left.30 \mathrm{sec}\right)$, and extension $\left(60^{\circ} \mathrm{C}\right.$ for $\left.30 \mathrm{sec}\right)$. Specific primers were used as follows: For human $P 21$ forward
(CTGAGACTCTCAGGGTCGAA) and reverse (CGGCGT TTGGAGTGGTAGAA); for human $M D M 2$ forward (TGG CGTGCCAAGCTTCTCTGT) and reverse (ACCTGAGTC CGATGATTCCTGCT); for human GAPDH forward (CAG CCTCAAGATCATCAGCA) and reverse (GTCTTCTGG GTGGCAGTGAT). The mRNA expressions of $M D M 2$ and $P 21$ were calculated using the $2^{-\Delta \Delta \mathrm{Cq}}$ method (34), with the GAPDH as an internal control, and data were represented as fold change.

Statistical analysis. All data are representative of three or more independent experiments. Data are presented as mean \pm standard error of the mean (SEM). Unpaired student's 

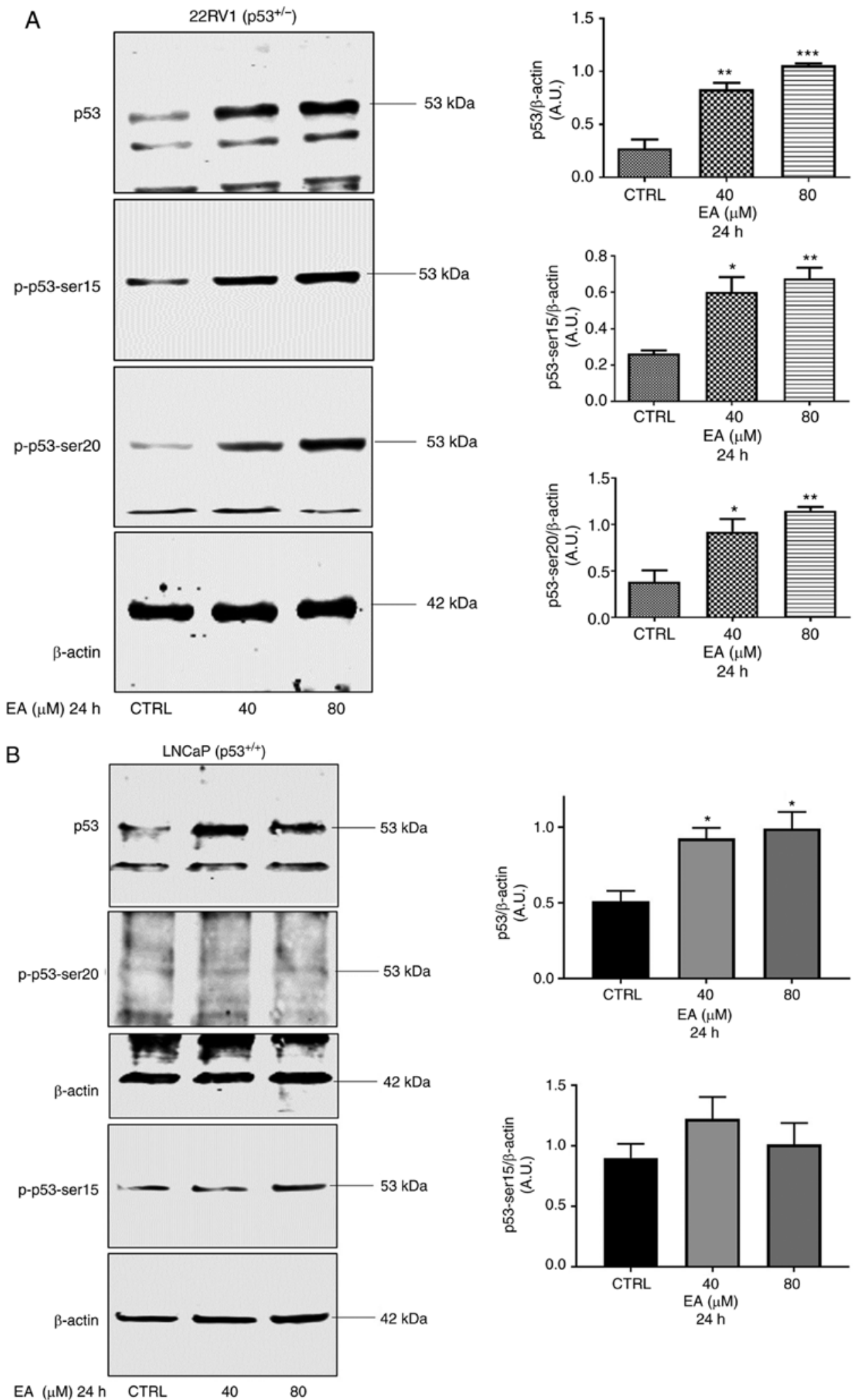

Figure 2. Representative western blotting of p53, p-p53-ser15, and p-p53-ser20 protein expression in PCa (A) 22RV1 and (B) LNCaP cells with their corresponding quantitative analyses. (A) In 22RV1 cells, EA significantly increased the protein expression of $\mathrm{p} 53$ ( $40 \mu \mathrm{M}, \mathrm{P}=0.0011 ; 80 \mu \mathrm{M} \mathrm{P}=0.0002)$, p-p53 ser 15 $(40 \mu \mathrm{M}, \mathrm{P}=0.0122 ; 80 \mu \mathrm{M}, \mathrm{P}=0.0047)$ and p-p53-ser $20(40 \mu \mathrm{M}, \mathrm{P}=0.0231 ; 80 \mu \mathrm{M}, \mathrm{P}=0.0046)$. (B) In addition, EA significantly increased the protein expression of 53 ( $40 \mu \mathrm{M}, \mathrm{P}=0.0164 ; 80 \mu \mathrm{M}, \mathrm{P}=0.0110)$ in LNCaP cells. Results are expressed as arbitrary units (A.U.) and represent the means \pm SEM of 3 experiments. ${ }^{*} \mathrm{P}<0.05,{ }^{* * *} \mathrm{P}<0.01,{ }^{* * *} \mathrm{P}<0.001$, significant result of 40 and $80 \mu \mathrm{M}$ EA vs. CTRL (vehicle control). PCa, prostate cancer; EA, ellagic acid; p-, phosphorylated.

T-test was used to compare two groups. One-way ANOVA, followed by Dunnett's multiple comparison tests were performed to compare three groups. Data were generated using GraphPad Prism v7.04 (GraphPad Software, Inc.). $\mathrm{P}<0.05$ was considered to indicate a statistically significant difference. 
A
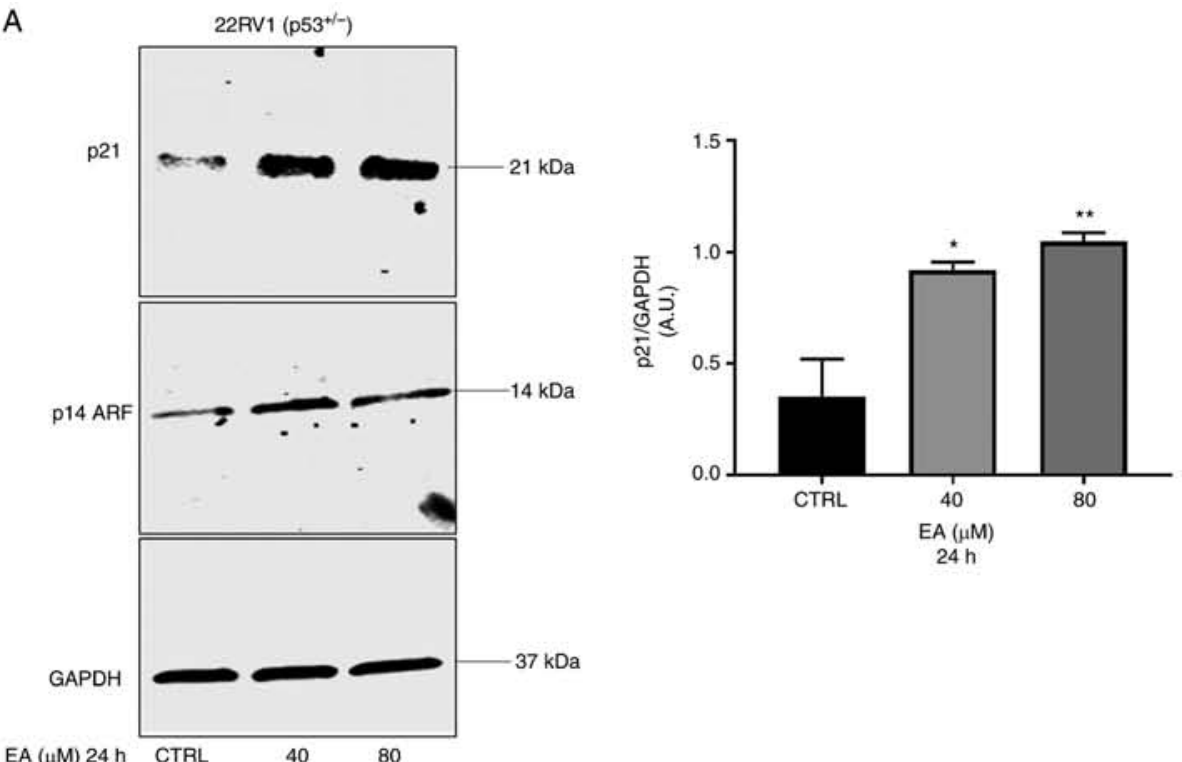

EA $(\mu \mathrm{M}) 24 \mathrm{~h} \quad$ CTRL $\quad 40 \quad 80$

B
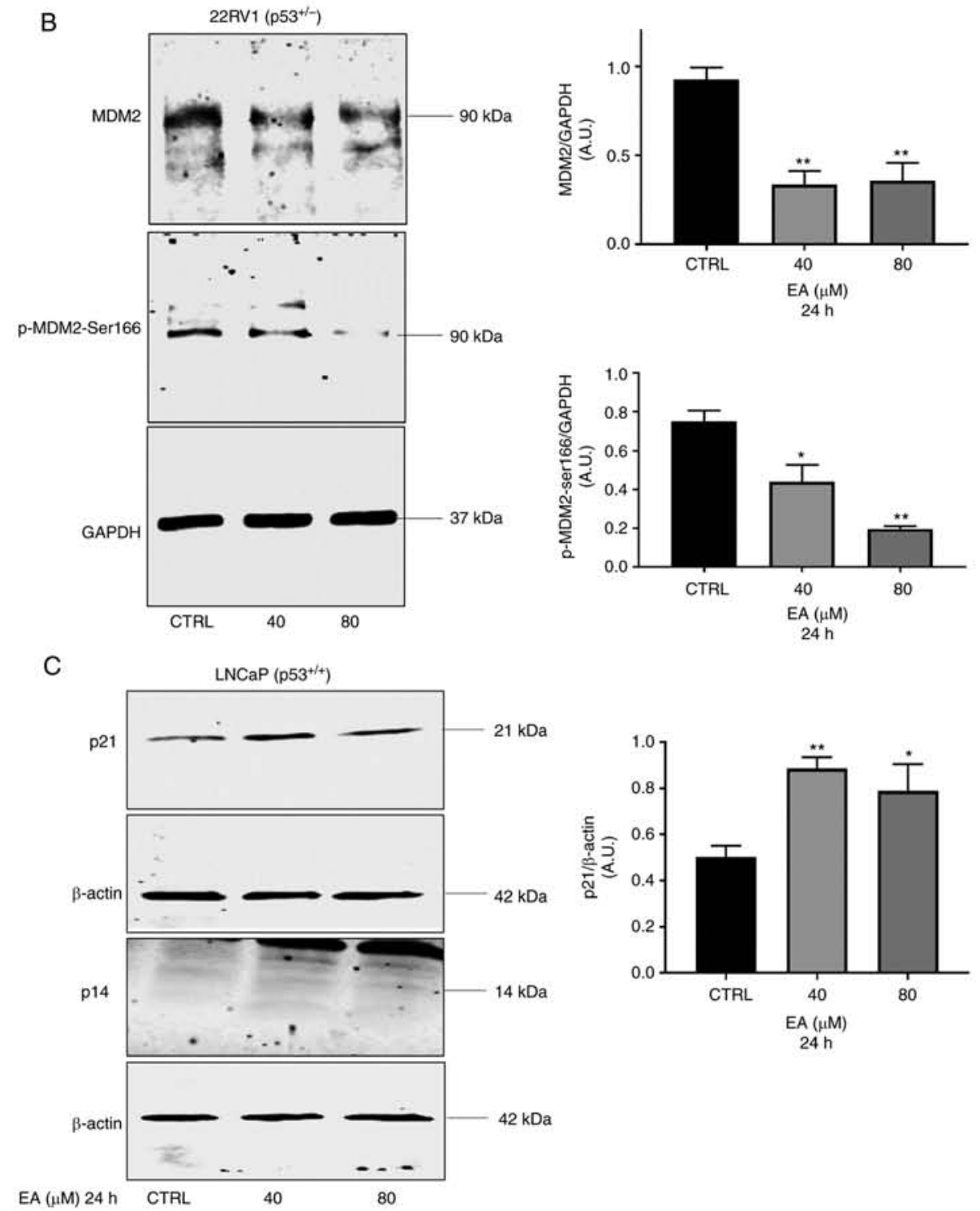

Figure 3. (A-D) Representative western blotting of MDM2, p-MDM2-ser166, p21, and p14ARF protein expression in PCa 22RV1, LNCaP, and PC3 cells with their corresponding quantitative analyses. EA significantly increased the protein expression of $\mathrm{p} 21$ in (A) $22 \mathrm{RV} 1$ cells $(40 \mu \mathrm{M}, \mathrm{P}=0.00137 ; 80 \mu \mathrm{M}, \mathrm{P}=0.0053)$, (C) LNCaP cells $(40 \mu \mathrm{M}, \mathrm{P}=0.0057 ; 80 \mu \mathrm{M}, \mathrm{P}=0.0363)$ and (E) PC3 cells (20 $\mu \mathrm{M}, \mathrm{P}=0.0025)$. (B) In 22RV1 cells, EA significantly decreased protein expression of MDM2 (40 $\mu \mathrm{M}, \mathrm{P}=0.044 ; 80 \mu \mathrm{M}, \mathrm{P}=0.0083)$, and $\mathrm{p}-\mathrm{MDM} 2$ at ser166 $(40 \mu \mathrm{M}, \mathrm{P}=0.0212 ; 80 \mu \mathrm{M}, \mathrm{P}=0.0013)$. 

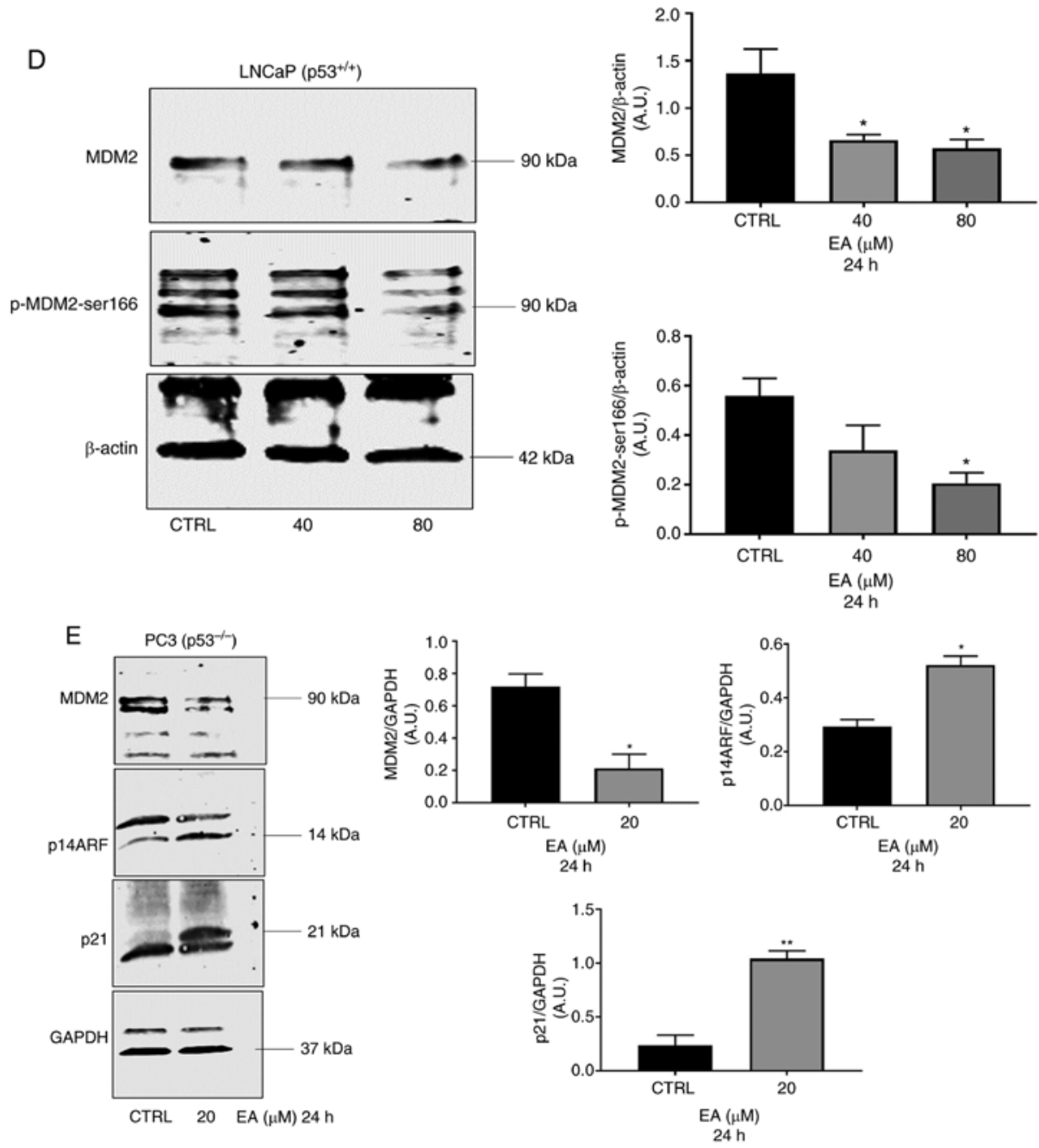

Figure 3 (Continued). (D) In LNCaP cells, EA significantly decreased MDM2 protein expression ( $40 \mu \mathrm{M}, \mathrm{P}=0.0282 ; 80 \mu \mathrm{M}, \mathrm{P}=0.0121)$, and p-MDM2 at ser166 $(80 \mu \mathrm{M}, \mathrm{P}=0.0221)$. (E) In PC3 cells, EA significantly decreased protein expression of MDM2 (20 $\mu \mathrm{M}, \mathrm{P}=0.0131)$ and significantly increased protein expression of p14ARF $(20 \mu \mathrm{M}, \mathrm{P}=0.0328)$. Results are expressed as arbitrary units (A.U.) and represent the means \pm SEM of 3 experiments. ${ }^{*} \mathrm{P}<0.05,{ }^{* *} \mathrm{P}<0.01$, significant result of 20, 40 and $80 \mu \mathrm{M}$ EA vs. CTRL (vehicle control). PCa, prostate cancer; EA, ellagic acid; p-, phosphorylated; MDM2, murine double minute-2.

\section{Results}

EA induces apoptosis in PCa cells. Different concentrations of EA were used for cell viability assay ranging from 5 to $160 \mu \mathrm{M}$ for 24 and $48 \mathrm{~h}$. For 22RV1 and LNCaP cell lines, EA did not promote any significant decrease in cell viability after $24 \mathrm{~h}$ of treatment compared with the vehicle control (Fig. 1A). Separately, for PC3 cells, EA significantly inhibited PC3 cell viability after $24 \mathrm{~h}$, starting at $20 \mu \mathrm{M}$. On the other hand,PCa cell viability was decreased in all cell lines after $48 \mathrm{~h}$ compared with the vehicle control (Fig. 1A; lower panel). We further confirmed the apoptotic effect at $24 \mathrm{~h}$ at 40 and $80 \mu \mathrm{M}$ EA in the LNCaP and 22RV1 cell lines (Fig. 1B). Although EA did not affect cell viability at $24 \mathrm{~h}$, it enhanced the expression of cleaved PARP in the LNCaP and 22RV1 cell lines compared with the vehicle control, suggesting apoptosis at $24 \mathrm{~h}$ following treatment with 40 and $80 \mu \mathrm{M}$ EA (Fig. 1B). For PC3 cells, cleaved caspase-3 was significantly increased after treatment with $20 \mu \mathrm{M}$ of EA for $24 \mathrm{~h}$ when compared with the vehicle control (Fig. 1B; right panel). Since we aimed to ascertain the effect of EA on MDM2 and p53 at the same concentrations that caused apoptosis, we continued to use 40 and $80 \mu \mathrm{M}$ for subsequent experiments.
EA increases p53 protein expression and enhances the expression of p53 target proteins. Following the results of apoptosis, we sought to investigate the effect of EA on p53 expression. The $\mathrm{p} 53$ protein level was significantly increased in $22 \mathrm{RV} 1$ and $\mathrm{LNCaP}$ with 40 and $80 \mu \mathrm{M}$ of EA at $24 \mathrm{~h}$ after treatment compared with the vehicle control (Fig. 2A and B). Previous studies have shown that many polyphenols increase p53 expression by inducing DNA damage (35); thus we investigated the effects of EA on p53 PTM, particularly phosphorylation. We found that EA increased phosphorylated p53 (p-p53) at ser15 and ser20 in the case of 22RV1 (Fig. 2A). On the other hand, the increase in phosphorylated p53 at ser15 was not significant in LNCaP following treatment with EA at both concentrations used, and no expression of phosphorylated p53 at ser20 was detected in LNCaP cells (Fig. 2B).

Next, we investigated the effects of EA on p53 main target proteins, MDM2, and p21. As expected, the protein level of p21 was increased by 40 and $80 \mu \mathrm{M}$ EA in both 22RV1 and LNCaP cell lines at $24 \mathrm{~h}$ compared with the vehicle control (Fig. 3A and C). Importantly, the p21 gene and protein expressions were also significantly elevated in PC3 $\left(\mathrm{p} 53^{-/}\right)$cells following $20 \mu \mathrm{M}$ EA at $24 \mathrm{~h}$ when compared with the vehicle 
A
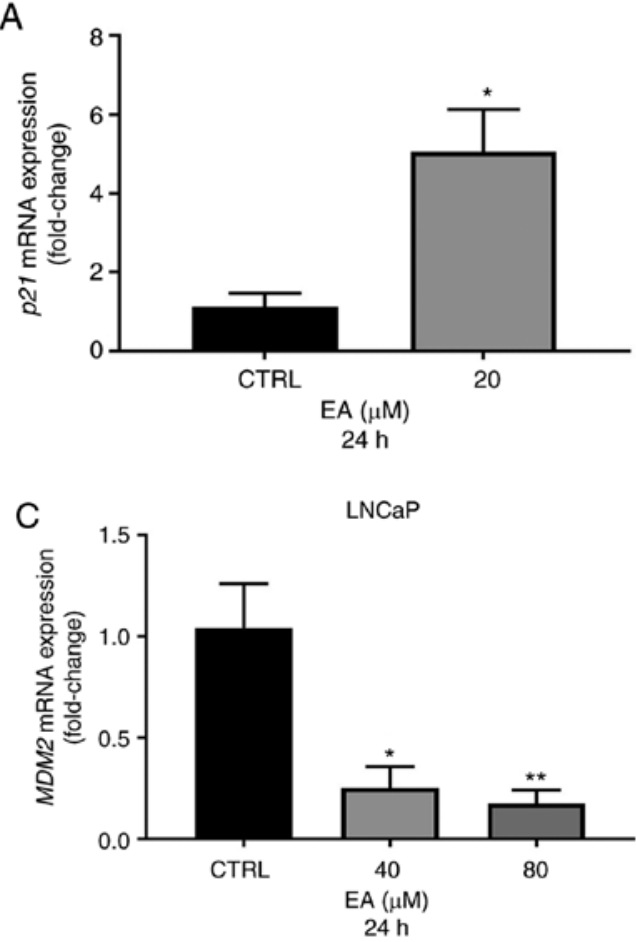

PC3
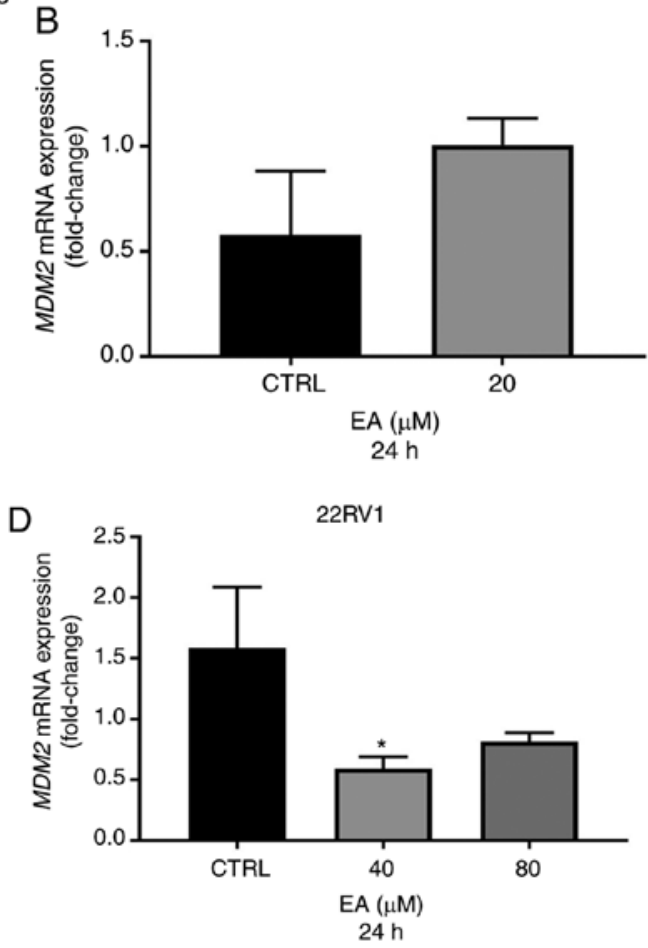

Figure 4. (A and B) Effect of EA on $M D M 2$ and $P 21$ mRNA levels in PCa PC3 cells using RT-qPCR. (A) EA at $20 \mu$ M significantly increased $P 21$ mRNA expression in PC3 cells ( $\mathrm{P}=0.0234)$. (B) The effect of EA on MDM2 mRNA in PC3 cells was not significant ( $\mathrm{P}=0.2239)$. (C and D) Effect of EA on MDM2 mRNA levels in LNCaP and 22RV1 cells using RT-qPCR. (C) EA at 40 and $80 \mu \mathrm{M}$ significantly decreased $M D M 2$ gene expression in LNCaP cells (40 $\mu \mathrm{M}$, $\mathrm{P}=0.0151 ; 80 \mu \mathrm{M}, \mathrm{P}=0.0099)$. (D) EA at $40 \mu \mathrm{M}$ significantly decreased $M D M 2$ gene expression in 22RV1 ( $\mathrm{P}=0.0433$ ). Bars represent $M D M 2 \mathrm{mRNA}$ in PCa cells treated with vehicle control (0.08\% DMSO) or with 40 or $80 \mu \mathrm{M}$ of EA for $24 \mathrm{~h}$. Data are expressed as fold-decrease compared with the vehicle control and normalized using GAPDH as an internal control and represent the mean means \pm SEM of 3 experiments. "P<0.05, ${ }^{* *} \mathrm{P}<0.01$ significant result of 20,40 or $80 \mu \mathrm{M}$ EA vs. CTRL (vehicle control). PCa, prostate cancer; EA, ellagic acid; MDM2, murine double minute-2.

control (Figs. 3E and 4A). Of note, although MDM2 is also a target gene for $\mathrm{p} 53$, the protein expression of MDM2 was significantly decreased in all cell lines examined in this study when compared with the vehicle control (Fig. 3B, D and E). Moreover, EA at 40 and $80 \mu \mathrm{M}$ downregulated phosphorylated MDM2 (p-MDM2) at ser166 in 22RV1 and LNCaP cells at $24 \mathrm{~h}$ when compared with the vehicle control (Fig. 3B and D). To further understand the nature of the MDM2 protein downregulation promoted by EA, we investigated the effects of EA on $M D M 2$ mRNA expression. As expected, 40 and $80 \mu \mathrm{M}$ EA caused the downregulation of $M D M 2$ gene expression in both $22 \mathrm{RV} 1$ and LNCaP cell lines at $24 \mathrm{~h}$ when compared with the vehicle control (Fig. 4C and D) although the decrease was not significant at $80 \mu \mathrm{M}$ in $22 \mathrm{RV} 1$ cells. However, the gene expression of $M D M 2$ was not significantly changed in PC3 cells following treatment with $20 \mu \mathrm{M}$ EA at $24 \mathrm{~h}$ when compared with the vehicle control (Fig. 4B). To further understand the MDM2 downregulation by EA, we also investigated the effects of EA on the MDM2/p14ARF pathway in PCa cells. Interestingly, p14ARF was markedly increased in 22RV1 and PC3 cells (Fig. 3A and E) but not in LNCaP cells (Fig. 3C).

EA induces apoptosis in a p53-dependent and-independent manner. p53 provokes apoptosis mainly through the induction of the pro-apoptotic proteins PUMA and NOXA (36). We therefore examined the effects of EA on expression levels of these proteins. As expected, EA increased the levels of PUMA and NOXA in 22RV1 and LNCaP cells at 40 and $80 \mu \mathrm{M}$ at
$24 \mathrm{~h}$ when compared with the vehicle control (Fig. 5A and B). To validate the apoptotic effect in PC 3 cells in the absence of p53, we separately found that EA significantly downregulated XIAP protein at $20 \mu \mathrm{M}$ at $24 \mathrm{~h}$ compared with the vehicle control, leading to increase cleaved caspase-3 (Fig. 5C). These data suggest that EA induces apoptosis in a p53-dependent and -independent manner by downregulating MDM2.

Effects of EA are independent of p53 and MDM2. The above results showed that EA induces PCa suppression via targeting MDM2 and activating p53. To further examine the effect of EA on the status of $\mathrm{p} 53$ and MDM2, we used MEF cells that have double knockouts for both 553 and MDM2 (p53 $3^{--}$MDM2 $2^{--}$). Cell viability assay showed that EA did inhibit MEF cell viability at the concentration range of from 5 to $160 \mu \mathrm{M}$ at $24 \mathrm{~h}$ in both the WT and double knockout MEF cells (Fig. 6A; upper panel). Moreover, EA induced cleaved caspase-3 expression In both the WT and double knockout MEF cells, suggesting apoptosis was induced independently of p53 and MDM2 (Fig. 6B; lower panel).

\section{Discussion}

EA is a naturally occurring polyphenolic compound that is derived from punicalagins (23). Although EA is known for its ability to induce cytotoxic effects in several types of cancer, including PCa (37), the influence of EA on MDM2 and p53 in $\mathrm{PCa}$ is not yet fully understood. We confirmed that EA induced 
A
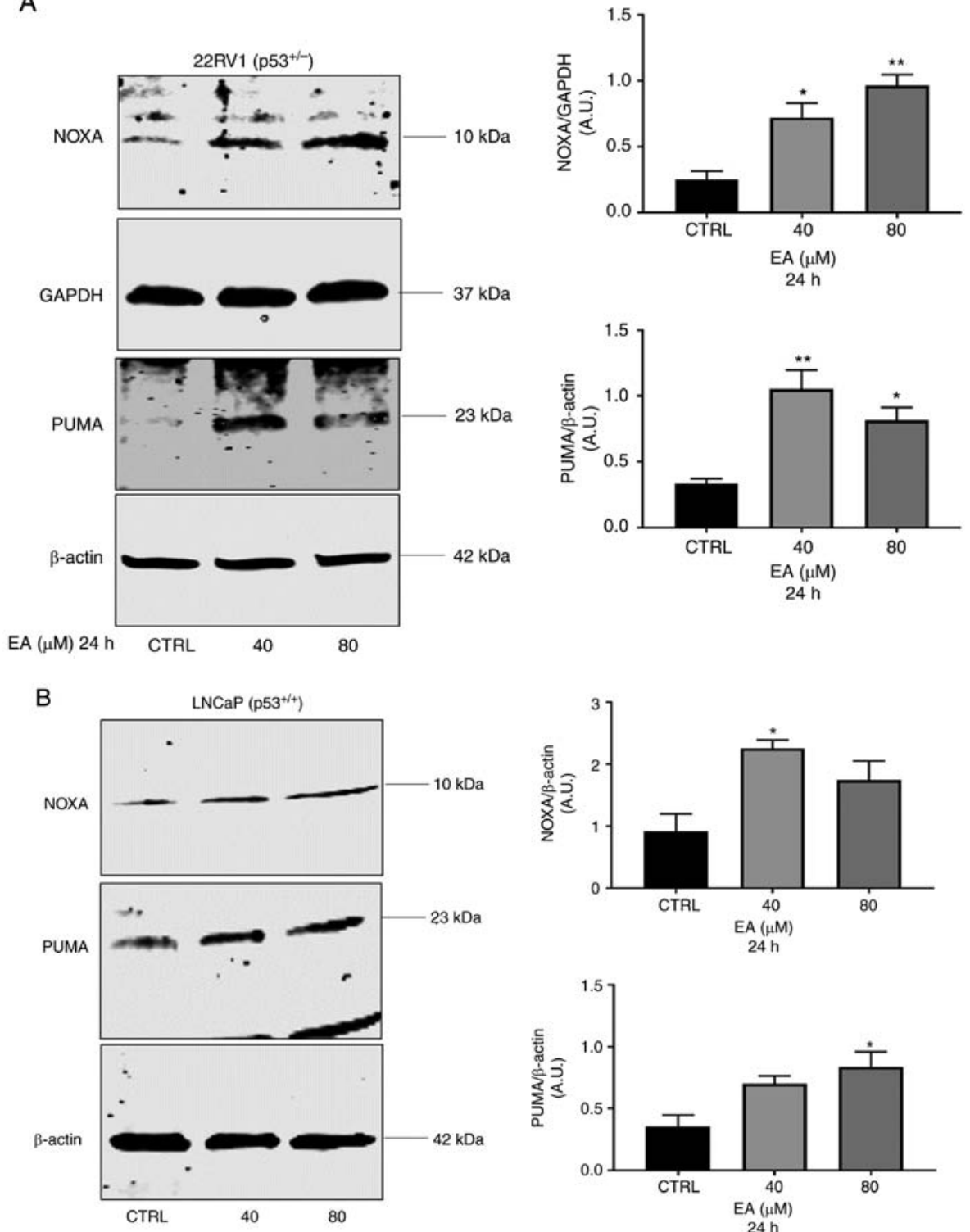

C
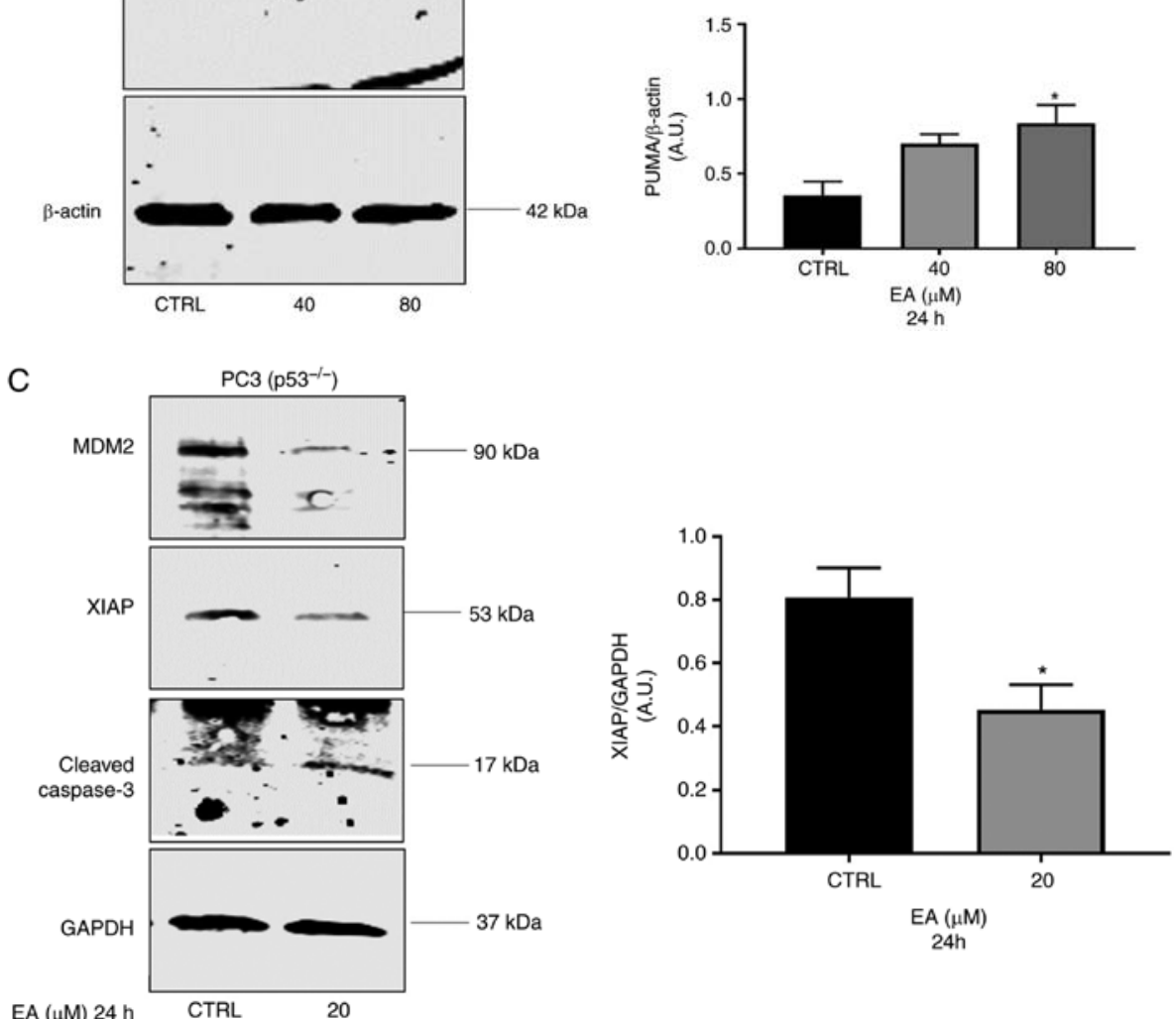

Figure 5. Representative western blotting of NOXA, and PUMA protein expression in PCa (A) 22RV1 and (B) LNCaP cells with their corresponding quantitative analyses. (A) EA significantly increased the protein expression of PUMA in $22 \mathrm{RV} 1(40 \mu \mathrm{M}, \mathrm{P}=0.0052 ; 80 \mu \mathrm{M}, \mathrm{P}=0.0173)$ and (B) LNCaP cells ( $80 \mu \mathrm{M}, \mathrm{P}=0.0362)$. EA also increased the level of NOXA protein expression in (A) 22RV1 $(40 \mu \mathrm{M}, \mathrm{P}=0.0172 ; 80 \mu \mathrm{M}, \mathrm{P}=0.0028)$, and (B) LNCaP cells $(40 \mu \mathrm{M}, \mathrm{P}=0.0432)$. (C) Representative western blotting of MDM2, XIAP and cleaved caspase 3 protein expression in PC3 cells. EA significantly increased the protein expression of XIAP (20 $\mu \mathrm{M}$, $\mathrm{P}=0.0436$ ). Results are expressed as arbitrary units (A.U.) and represent the means $\pm \mathrm{SEM}$ of 3 experiments. ${ }^{*} \mathrm{P}<0.05,{ }^{* *} \mathrm{P}<0.01$, significant result of 20,40 and $80 \mu \mathrm{M}$ EA vs. vs. CTRL (vehicle control). PCa, prostate cancer; EA, ellagic acid; MDM2, murine double minute-2; PUMA, p53 upregulated modulator of apoptosis [also known as Bcl-2-binding component 3 (BBC3)]; NOXA, Phorbol-12-myristate-13-acetate-induced protein 1; XIAP, X-linked inhibitor of apoptosis protein. 
A

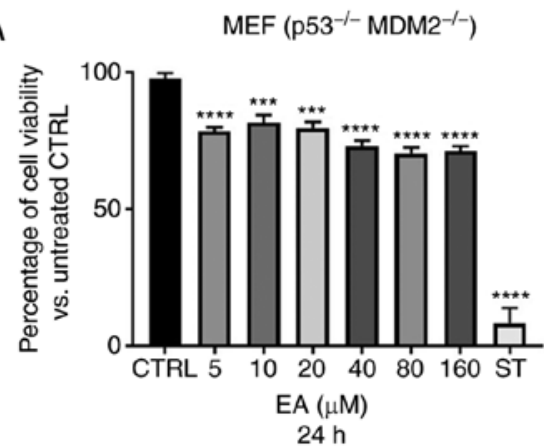

B

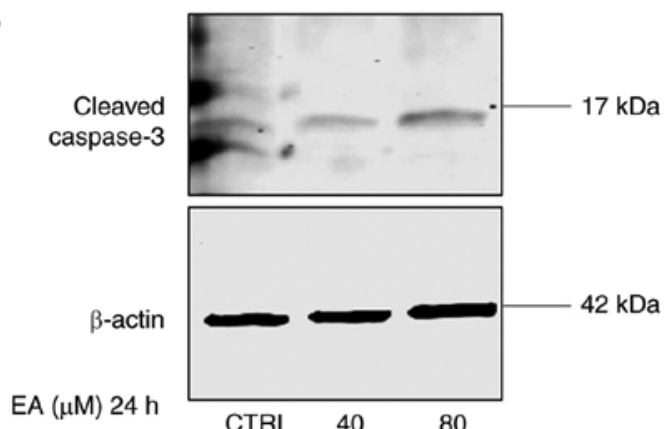

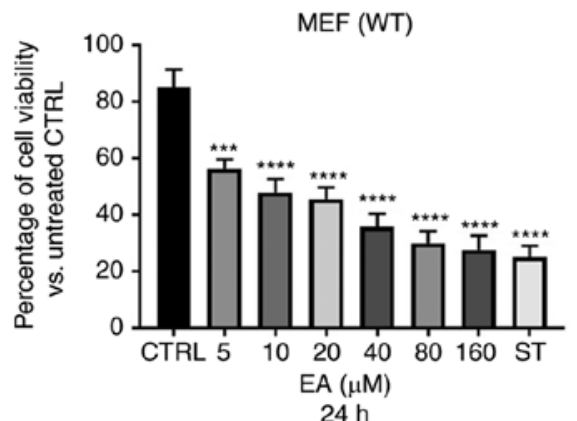

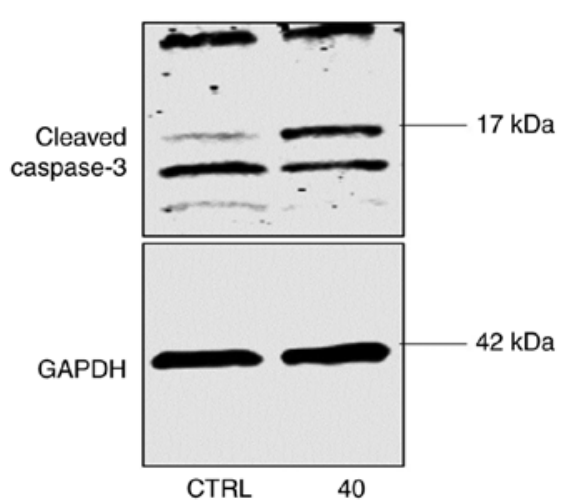

Figure 6. (A) Cell viability assay for the effect of EA on MEF cells (p53 $3^{-/-} \mathrm{MDM} 2^{-/-}$) and wild-type (WT) MEF cells. Cell Titer-Glo assays were performed to determine the cell viability of MEF cells. The percentages of viable cells were determined relevant to untreated cells as compared to vehicle control (CTRL). One-way ANOVA of three measurements in triplicate (mean \pm SEM) was performed. ${ }^{* * *} \mathrm{P}<0.001,{ }^{* * * *} \mathrm{P}<0.0001$ significant results of different concentrations of

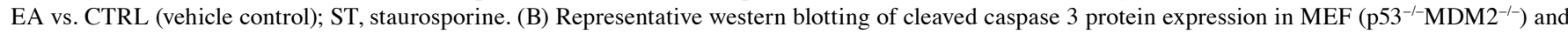
MEF (WT) cells. EA, ellagic acid; MEF, mouse embryonic fibroblast; MDM2, murine double minute-2.

apoptosis by increasing the expression of cleaved PARP in LNCaP, 22RV1, and PC3 cell lines, although no significant effect was found on the viability of PCa cells after $24 \mathrm{~h}$. We assumed this discrepancy between cell viability assay and apoptosis after $24 \mathrm{~h}$ is that apoptosis is an early event in cell death, while cell viability is reduced at the late stage of apoptosis. We further confirmed this by analyzing the viability after $48 \mathrm{~h}$, finding that EA suppressed PCa cell viability. Moreover, we chose 40 and $80 \mu \mathrm{M}$ as these two concentrations caused a significant effect on apoptosis after $24 \mathrm{~h}$. Since we aimed to ascertain the effect of EA on MDM2 and p53 at the same concentrations that caused apoptosis, we used 40 and $80 \mu \mathrm{M}$ for all other experiments. To note, EA reduced the LNCaP cell viability at a low concentration. In a separate experiment, we found that EA induced apoptosis at a low concentration but without affecting the p53 and MDM2 at low concentration (data not shown). We conclude that EA can induce apoptosis at a low concentration in a pathway that is independent of the p53-MDM2 pathway; such a pathway requires a high concentration of EA to get stimulated. Vanella et al (28) showed that EA induced $\mathrm{LNCaP}$ cell death by targeting the mTOR pathway and lowering the intracellular level of $\beta$-catenin. Moreover, their study also showed that EA increased the expression of p21 in LNCaP cells (28).

In the present study, we demonstrated the influences of EA on the $\mathrm{p} 53 / \mathrm{MDM} 2$ pathway in PCa in vitro using three models of PCa that each harbor a distinct TP53 gene. Our western blot data indicated that EA increased the p53 protein level. p53 activation is mainly regulated by phosphorylation and acetylation, which are part of the post-translation modification (PTM) of p53 (6). Phosphorylation of p53 at ser15 occurred as a response to DNA damage that resulted from a single- or double-strand break (38). Previous research has shown that other polyphenols induce p53 expression by inducing DNA damage, which triggers the ATM/CHK kinases that cause phosphorylation to the p53 (35). Here, we found that EA induced phosphorylation of p53 at ser15 in 22RV1 cells, indicating a DNA damage mechanism induced by EA in 22RV1 cells. However, p53-ser 15 was not significantly increased after EA treatment in LNCaP cells, suggesting that EA does not produce DNA damage effects in LNCaP as it does in 22RV1 cells. Prior research showed that phosphorylation of p53 at ser20 weakens the interaction between p53 and MDM2 (19). In our study, we found EA only induces the phosphorylation of p53 at ser20 in 22RV1 cells, but not in LNCaP cells. Moreover, the increased level of p53 protein achieved by EA was accompanied by increases in p53's main target protein, p21, in both 22RV1 and LNCaP cells, suggesting cell-cycle arrest of PCa by EA in these cells. This finding is in agreement with those previously reported by Vanella et al $(28,29)$. p53 is negatively regulated by MDM2, which itself is a target gene of p53, forming an autoregulatory feedback loop. We recently found that a metabolite of EA, urolithin A (UA), increased p53 protein expression, and that this increase was accompanied by increases in MDM2 gene and protein expression, forming an autoregulatory feedback loop (32). Interestingly, although the level of p53 was increased by EA, we found that EA did not increase MDM2 protein expression as a feedback loop but did downregulate it. We speculated the MDM2 downregulation by EA may be occurring at the transcriptional level or via other MDM2 regulators. 
p14ARF, another tumor suppressor, is known to inhibit the p53-MDM2 interaction and MDM2 ligase activity (39). A previous study revealed that apigenin downregulated MDM2 by increasing p14ARF in 22RV1 cells (40). In 22RV1 and PC3 cells treated with EA, we found that p14ARF was increased, suggesting a possible mechanism of MDM2 downregulation by EA. However, p14AFR was not increased in LNCAP cells, indicating that EA may affect either the gene expression of MDM2 or affect MDM2 at the protein level. Our data showed that EA downregulated MDM2 mRNA in LNCaP and 22RV1 cells, further explaining the MDM2 protein downregulation. We concluded that the downregulation of MDM2 by EA suggested that EA inhibited the ligase activity of MDM2, preventing p53 ubiquitination and degradation. On the other hand, the MDM2 mRNA level was not altered in PC3 cells, suggesting that EA downregulates MDM2 protein expression by inducing $\mathrm{p} 14 \mathrm{ARF}$ or that EA may affect MDM2 protein directly. Interestingly, the gene and protein expressions of $\mathrm{p} 21$ were also increased in PC3 cells independently of p53. These results are in agreement with those of a previous study that confirmed p21 expression in the absence of p53 (41). Moreover, MDM2 itself can negatively regulate p21 in a p53-independent manner (42). Therefore, we speculate that the MDM2 downregulation by EA in PC3 cells may aid in the increased in protein expression of $\mathrm{p} 21$. It is known that $\mathrm{p} 53$ produces apoptosis when the p53 protein level reaches the apoptotic threshold (43). Upon reaching the apoptotic threshold, p53 induces the expression of two main pro-apoptotic proteins, p53 upregulated modulator of apoptosis (PUMA) [also known as Bcl-2-binding component 3 (BBC3)] and Phorbol-12-myristate-13-acetate-induced protein 1 (NOXA). (36). PUMA and NOXA can bind the mitochondrial antiapoptotic proteins Bcl-2, Bcl-X, and MCL-1 (36), producing an intrinsic apoptotic effect. In the present study, the increased level of p53 by EA was accompanied by increases in PUMA and NOXA, suggesting p53-dependent apoptosis by EA.

MDM2 is phosphorylated by AKT at ser166, enabling it to enter the nucleus, where it binds and inhibits the transcriptional activity of p53 (44). In the present study, we found that EA downregulated phosphorylated MDM2 in LNCaP and 22RV1 cells at ser166, restoring the activity of p53 and its target genes. Our data on mouse embryonic fibroblasts (MEFs) (p53 $3^{--}, \mathrm{MDM}^{--/}$) suggest that the influence of EA on the p53-MDM2 pathway may be partly contributed to the cytotoxic effect of EA on PCa.

All these mechanisms of EA on the p53-MDM2 pathway demonstrate its effectiveness in suppressing PCa through this pathway in vitro. However, EA has low bioavailability after consumption of pomegranate or other dietary sources in other fruits (45). The poor bioavailability of EA will eventually limit the metabolically active urolithins, limiting the therapeutic effectiveness of these compounds after consumption of pomegranate (46). In the current study, we selected 40 and $80 \mu \mathrm{M}$ concentrations of EA and UA because they showed significant apoptotic effect after a 24-h treatment and a significant effect on p53 and its target genes and proteins in vitro. We acknowledge that these concentrations are not bioavailable after consumption of pomegranate. Therefore, the current research suggests that EA can be useful to treat $\mathrm{PCa}$ if both are extracted from pomegranate or other dietary sources. Furthermore, there are recent efforts by researchers to improve the bioavailability of
EA $(47,48)$, which will focus on improving EA drug delivery to cancer sites, including PCa.

In conclusion, this study demonstrated the role of the natural polyphenol EA in the suppression of PCa cell growth by inhibiting the oncogene $M D M 2$ and inducing p53 protein expression and its target proteins. However, further experiments are required to validate these data; for example, using luciferase reporter assay for p53 before and after EA treatment in PCa cells will be useful to validate the gene expression by p53. Moreover, RNA-seq analysis will be useful to validate the alteration in gene expression by p53. Additionally, it may be useful to observe the effect of EA on AKT to validate the EA effect on the phosphorylated MDM2 at ser-166. Furthermore, Annexin $\mathrm{V}$ apoptotic assay using flow cytometry will be helpful in validating the apoptotic effect by EA. A major problem with MDM2 inhibitors is that they produce p53 accumulation in normal cells, causing toxicity to normal cells. Therefore, further research is needed to examine the concept of p53 accumulation in a normal prostate cell line provoked by EA.

\section{Acknowledgements}

Not applicable.

\section{Funding}

The present study was funded by the Department of Pharmacology and Toxicology at East Carolina University (Greenville, NC, USA).

\section{Availability of data and materials}

The datasets used during the present study are available from the corresponding author upon reasonable request.

\section{Authors' contributions}

YIMS and MS conceptualized the study. YIMS designed the study and performed all the experiments and analyzed the data. YIMS wrote the manuscript, and MS revised the manuscript. All authors read and approved the final manuscript.

\section{Ethics approval and consent to participate}

Not applicable.

\section{Patient consent for publication}

Not applicable.

\section{Competing interests}

The authors declare that they have no competing interests.

\section{References}

1. Ferlay J, Soerjomataram I, Dikshit R, Eser S, Mathers C, Rebelo M, Parkin DM, Forman D and Bray F: Cancer incidence and mortality worldwide: Sources, methods and major patterns in GLOBOCAN 2012. Int J Cancer 136: E359-E386, 2015. 
2. Wirth MP, Hakenberg OW and Froehner M: Antiandrogens in the treatment of prostate cancer. Eur Urol 51: 306-313, discussion $314,2007$.

3. Logan IR, McNeill HV, Cook S, Lu X, Lunec J and Robson CN Analysis of the MDM2 antagonist nutlin-3 in human prostate cancer cells. Prostate 67: 900-906, 2007.

4. Toufektchan E and Toledo F: The guardian of the genome revisited: p53 downregulates genes required for telomere maintenance, DNA repair, and centromere structure. Cancers (Basel) 10: 135, 2018.

5. Brady CA and Attardi LD: p53 at a glance. J Cell Sci 123: 2527-2532, 2010.

6. Jin L, Li C, Xu Y, Wang L, Liu J, Wang D, Hong C, Jiang Z, Ma Y, Chen Q and Yu F: Epigallocatechin gallate promotes p53 accumulation and activity via the inhibition of MDM2-mediated p53 ubiquitination in human lung cancer cells. Oncol Rep 29: 1983-1990, 2013

7. Kruse JP and Gu W: SnapShot: p53 posttranslational modifications. Cell 133: 930-30.e1, 2008

8. Muñoz-Fontela C, González D, Marcos-Villar L, Campagna M, Gallego P, González-Santamaría J, Herranz D, Gu W, Serrano M, Aaronson SA and Rivas C: Acetylation is indispensable for p53 antiviral activity. Cell Cycle 10: 3701-3705, 2011.

9. Sakaguchi K, Herrera JE, Saito S, Miki T, Bustin M, Vassilev A Anderson CW and Appella E: DNA damage activates p53 through a phosphorylation-acetylation cascade. Genes Dev 12: 2831-2841, 1998.

10. Jimenez GS, Khan SH, Stommel JM and Wahl GM: p53 regulation by post-translational modification and nuclear retention in response to diverse stresses. Oncogene 18: 7656-7665, 1999.

11. Lee JT and Gu W: The multiple levels of regulation by $\mathrm{p} 53$ ubiquitination. Cell Death Differ 17: 86-92, 2010

12. Yuan J, Luo K, Zhang L, Cheville JC and Lou Z: USP10 regulates p53 localization and stability by deubiquitinating p53. Cell 140 : 384-396, 2010

13. Olivier M, Hollstein M and Hainaut P: TP53 mutations in human cancers: Origins, consequences, and clinical use. Cold Spring Harb Perspect Biol 2: a001008, 2010.

14. Robles AI and Harris CC: Clinical outcomes and correlates of TP53 mutations and cancer. Cold Spring Harb Perspect Biol 2: a001016, 2010

15. Leite KR, Franco MF, Srougi M, Nesrallah LJ, Nesrallah A, Bevilacqua RG, Darini E, Carvalho CM, Meirelles MI, Santana I and Camara-Lopes LH: Abnormal expression of MDM2 in prostate carcinoma. Mod Pathol 14: 428-436, 2001

16. Bohlman S and Manfredi JJ: p53-independent effects of Mdm2. Subcell Biochem 85: 235-246, 2014.

17. Alarcon-Vargas D and Ronai Z: p53-Mdm2 - the affair that never ends. Carcinogenesis 23: 541-547, 2002.

18. Nag S, Qin J, Srivenugopal KS, Wang M and Zhang R: The MDM2-p53 pathway revisited. J Biomed Res 27: 254-271, 2013.

19. Moll UM and Petrenko O: The MDM2-p53 interaction. Mol Cancer Res 1: 1001-1008, 2003.

20. Khan N, Bharali DJ, Adhami VM, Siddiqui IA, Cui H, Shabana SM, Mousa SA and Mukhtar H: Oral administration of naturally occurring chitosan-based nanoformulated green tea polyphenol EGCG effectively inhibits prostate cancer cell growth in a xenograft model. Carcinogenesis 35: 415-423, 2014.

21. Robson $\mathrm{CH}$, Ganapathy M, Swanson GP, Natarajan M, Papanikolaou N, Hanes MA, Yeh IT, Ghosh R and Kumar AP: Phellodendron amurense bark extract enhances radiosensitivity by inhibition of nf-kappa B in transgenic adenocarcinoma of mouse prostate model and human prostate cancer cells. J Urol 181 (4S): 479, 2009

22. Paller CJ, Pantuck A and Carducci MA: A review of pomegranate in prostate cancer. Prostate Cancer Prostatic Dis 20: 265-270, 2017.

23. Seeram NP, Adams LS, Henning SM, Niu Y, Zhang Y, Nair MG and Heber D: In vitro antiproliferative, apoptotic and antioxidant activities of punicalagin, ellagic acid and a total pomegranate tannin extract are enhanced in combination with other polyphenols as found in pomegranate juice. J Nutr Biochem 16: 360-367, 2005.

24. Han DH, Lee MJ and Kim JH: Antioxidant and apoptosis-inducing activities of ellagic acid. Anticancer Res 26 : 3601-3606, 2006.

25. Naiki-Ito A, Chewonarin T, Tang M, Pitchakarn P, Kuno T, Ogawa K, Asamoto M, Shirai T and Takahashi S: Ellagic acid, a component of pomegranate fruit juice, suppresses androgen-dependent prostate carcinogenesis via induction of apoptosis. Prostate 75: 151-160, 2015.
26. Losso JN, Bansode RR, Trappey A II, Bawadi HA and Truax R: In vitro anti-proliferative activities of ellagic acid. J Nutr Biochem 15: 672-678, 2004.

27. Malik A, Afaq S, Shahid M, Akhtar K and Assiri A: Influence of ellagic acid on prostate cancer cell proliferation: A caspase-dependent pathway. Asian Pac J Trop Med 4: 550-555, 2011

28. Vanella L, Di Giacomo C, Acquaviva R, Barbagallo I, Cardile V, Kim DH, Abraham NG and Sorrenti V: Apoptotic markers in a prostate cancer cell line: Effect of ellagic acid. Oncol Rep 30: 2804-2810, 2013.

29. Vanella L, Di Giacomo C, Acquaviva R, Barbagallo I, Li Volti G, Cardile V, Abraham NG and Sorrenti V: Effects of ellagic acid on angiogenic factors in prostate cancer cells. Cancers (Basel) 5: 726-738, 2013

30. Wang L, Li W, Lin M, Garcia M, Mulholland D, Lilly M and Martins-Green M: Luteolin, ellagic acid and punicic acid are natural products that inhibit prostate cancer metastasis. Carcinogenesis 35: 2321-2330, 2014.

31. Zhang HM, Zhao L, Li H, Xu H, Chen WW and Tao L: Research progress on the anticarcinogenic actions and mechanisms of ellagic acid. Cancer Biol Med 11: 92-100, 2014.

32. Mohammed Saleem YI, Albassam H and Selim M: Urolithin A induces prostate cancer cell death in p53-dependent and in p53-independent manner. Eur J Nutr 59: 1607-1618, 2019.

33. Van Dross RT: Metabolism of anandamide by COX-2 is necessary for endocannabinoid-induced cell death in tumorigenic keratinocytes. Mol Carcinog 48: 724-732, 2009.

34. Livak KJ and Schmittgen TD: Analysis of relative gene expression data using real-time quantitative PCR and the 2(-Delta Delta C(T)) method. Methods 25: 402-408, 2001.

35. Nelly Etienne-Selloum ID, Tanveer Sharif CAa, Schini-Kerth VB: Polyphenolic Compounds Targeting p53-Family Tumor Suppressors: Current Progress and Challenges, 2013.

36. Khoo KH, Verma CS and Lane DP: Drugging the p53 pathway: Understanding the route to clinical efficacy. Nat Rev Drug Discov 13: 217-236, 2014.

37. Ceci C, Lacal PM, Tentori L, De Martino MG, Miano R and Graziani G: Experimental evidence of the antitumor, antimetastatic and antiangiogenic activity of ellagic acid. Nutrients 10: $1756,2018$.

38. Loughery J, Cox M, Smith LM and Meek DW: Critical role for p53-serine 15 phosphorylation in stimulating transactivation at p53-responsive promoters. Nucleic Acids Res 42: 7666-7680, 2014.

39. Agrawal A, Yang J, Murphy RF and Agrawal DK: Regulation of the p14ARF-Mdm2-p53 pathway: An overview in breast cancer. Exp Mol Pathol 81: 115-122, 2006.

40. Shukla S and Gupta S: Apigenin-induced prostate cancer cell death is initiated by reactive oxygen species and p53 activation. Free Radic Biol Med 44: 1833-1845, 2008.

41. Aliouat-Denis CM, Dendouga N, Van den Wyngaert I, Goehlmann H, Steller U, van de Weyer I, Van Slycken N, Andries L, Kass S, Luyten W, et al: p53-independent regulation of p21Waf1/Cip1 expression and senescence by Chk2. Mol Cancer Res 3: 627-634, 2005

42. Zhang Z, Wang H, Li M, Agrawal S, Chen X and Zhang R: MDM2 is a negative regulator of $\mathrm{p} 21 \mathrm{WAF} 1 / \mathrm{CIP} 1$, independent of p53. J Biol Chem 279: 16000-16006, 2004.

43. Kracikova M, Akiri G, George A, Sachidanandam R and Aaronson SA: A threshold mechanism mediates p53 cell fate decision between growth arrest and apoptosis. Cell Death Differ 20: 576-588, 2013.

44. Meek DW and Knippschild U: Posttranslational modification of MDM2. Mol Cancer Res 1: 1017-1026, 2003.

45. Seeram NP, Lee R and Heber D: Bioavailability of ellagic acid in human plasma after consumption of ellagitannins from pomegranate (Punica granatum L.) juice. Clin Chim Acta 348: 63-68, 2004.

46. Bell C and Hawthorne S: Ellagic acid, pomegranate and prostate cancer-a mini review. J Pharm Pharmacol 60: 139-144, 2008.

47. Bala I, Bhardwaj V, Hariharan S, Kharade SV, Roy N and Ravi Kumar MN: Sustained release nanoparticulate formulation containing antioxidant-ellagic acid as potential prophylaxis system for oral administration. J Drug Target 14: 27-34, 2006

48. Jeong YI, Prasad Yv R, Ohno T, Yoshikawa Y, Shibata N, Kato S, Takeuchi K and Takada K: Application of Eudragit P-4135F for the delivery of ellagic acid to the rat lower small intestine. J Pharm Pharmacol 53: 1079-1085, 2001. 